\title{
Governance and Pro-poor Growth: Evidence from Pakistan
}

\author{
RASHIDA HAQ and UZMA ZIA
}

\section{INTRODUCTION}

The issue of governance has gained importance over the last two decades and became a key component of policies for economic development. Good governance acts as a positive force to influence economic growth. A growing amount of available evidence suggests that lack of quality governance hinders growth and investment, and aggravates poverty and inequality. In fact, governance problem foil every effort to improve infrastructure, attract investment, and raise educational standard. As the developing countries are characterised by weak institutions, low growth, poverty and inequality all which translate into low levels of human development. The multiplicative effects of these outcomes result in poverty traps that are extremely difficult to break out. This state of affairs has forced governments to embark on a wide range of reforms in their institutions of governance and economies with the goal of achieving economic growth.

Good governance can lead a country to achieve high and sustained economic growth by establishing conducive environment for saving and investment, risk taking, providing incentives to producers, creating certainty in markets, increasing the size of markets by removing barriers to international trade and improvements in competitiveness.

Does good governance constitute to pro-poor growth? The concept of good governance has taken central stage in development thinking and practice since the 1990s. It has been increasingly viewed as a key ingredient for development; the decade also witnessed a renewed focus on poverty reduction as the major goal of development. Several reasons account for the increasing attention to governance and institutions by the international development community, among them research findings demonstrating the financial aid effectiveness depends on "a good policy environment". The lacklustre performance of structural adjustment programme initiated in 1988, political problem and institutional weakness have contributed to the new focus on governance.

The emphasis on reforming economies to achieve high rates of economic growth is largely motivated by the fact that economic growth associates with lower poverty rates and improvements in the quality of life. It is assumed that there is a strong link between economic growth and poverty reduction but this relationship does not always hold. It is

Rashida Haq <rashida_haq@hotmail.com> and Uzma Zia <uzia05@yahoo.com> are Research Economist and Staff Economist, respectively, at the Pakistan Institute of Development Economics, Islamabad.

Authors' Note: We are indebted to Ms Attiya Yasmin Javid, Research Economist, Pakistan Institute of Development Economics, Islamabad, for her insightful comments on earlier drafts of this paper. 
observed that different episodes of growth could have substantially different impact on poverty even in the same country. So the key policy concern is to institute economic reforms that results in economic growth associated with substantial gains to the poor, referred as pro-poor growth. Promoting pro-poor growth has now become a major goal in the strategies of international donor organisations.

Since both governance and pro-poor growth are high on the development policy agenda, the question arises as to whether and how they are related to each other. It is commonly assumed that good governance promotes pro-poor growth, this analysis empirically test this challenging assumption that links governance indicators with the joint outcomes of growth, inequality and poverty reduction which together underlie the concept of pro-poor growth. These linkages are also discussed from the available crosscountry literature.

This paper is organised as follows: Section 1 is introduction providing importance and objectives of the study. Section 2 presents a literature review, while Section 3 define and measure governance dimensions and pro-poor growth. Section 4 presents empirical analysis to show linkages between governance and pro-poor growth. Concluding remarks are discussed in Section 5.

\section{LITERATURE REVIEW}

This section discusses the cross-country studies examining the interaction between the governance and pro-poor growth.

Ahmed (2001) analysed the political economy aspects of poverty reduction in South Asia by developing a framework for measuring governance performance and relating this performance to poverty trends. He argued that governance appears to be a significant problem in South Asia with associated adverse implication for poverty reduction.

Kaufmann and Aart (2002) suggested that per capita income and the quality of governance are strongly positively correlated across countries. They proposed an empirical strategy that allows separating this correlation into two parts. First, a strong positive casual effect running from better governance to higher per capita. The result confirmed existing evidence on income; the importance of good governance for economic development. Second, a weak even negative casual effect running from in the opposite direction from per capita income to governance. This resulted in the absence of "Virtuous Circles" in which higher incomes lead to further improvement in governance.

Chatterjee, et al. (2006) aimed to address, "why is economic growth in Bangladesh not pro-poor given the various shifts and changes in the economy since 1990"? They concluded that weak political institutions and the skewed distribution of economic resources as well as political capital had resulted in relatively more de facto political power in the hands of a few, which in turn is, hindering the process of pro-poor growth.

Kimnenyi (2005) presented a general theory of pro-poor growth that includes ten principles that should be incorporated in all economic reforms that seek to generate propoor growth. These principles highlighted the importance of understanding the poor, their economic activities, capabilities and constraints that impede their participation in markets and also an appreciation of linkages within sectors and regions. He argued that pro-poor reforms cannot have the intended impact unless there are significant changes in the 
institutions of governance. He concluded that these principles under score the fact that pro-poor growth policies cannot be sustained without workable partnerships between markets and states in the ever changing and complex process of social and economic development.

Resnick and Regina (2006) developed a conceptual framework that specified the linkages between different aspects of governance and pro-poor growth. Using this framework, the paper reviewed a range of quantitative cross-country studies that include measures of governance as independent variables and focuses on the dependent variable in at least two of three dimensions of pro-poor growth: poverty, inequality and growth. The review showed that governance indicators, such as political stability and rule of law are associated with growth but provide mixed results regarding poverty reduction. On the other hand, governance indicators that refer to transparent political systems, such as civil liberties and political freedom, tend to conduce for poverty reduction, but the evidence is rather mixed and the relationship of these variables with growth remains unclear.

Pasha (2000) identified nine elements of good economic governance as achievement of growth with equity, fiscal discipline, institutional capacity, credibility and consistency, protection of public interest, ability to manage crisis, effective delivery of services, integrity and sovereignty. He concluded that based on these measures of good economic governance, Pakistan's economic performance was mixed one with visible sign of deterioration in 90s. He suggested that if Pakistan's economy has to emerge once again as a relatively high growth performer the quality of economic governance will have to be of the highest level.

Mahbub ul Haq Human Development Centre (1999) illustrated that South Asia had emerged by now as one of the most poorly governed regions in the world, with exclusion of the voiceless majority, unstable political regimes, and poor economic management. It also analysed that the systems of governance have become unresponsive and irrelevant to the need and concerns of people.

Dollar and Kraay (2002) found that the rule of law indicators is positively and significantly correlated with growth in per capita incomes of the poorest quintile. They concluded that greater rule of law may be associated with a greater share of growth accruing to the lowest 20 percent of the population. This is predominantly due to the indicator's influence through growth rather than through improving distribution.

Chong and Gradstein (2004) discovered that the political stability and rule of law all exhibit a negative and significant relation with inequality as measured by the Gini coefficient. In other words, better governance indicators lead to a decrease in inequality. Moreover, the impact of income distribution on political institutions is greater in developing countries than in industrialised ones.

Lopez (2004) assessed whether policies that are pro growth are also pro-poor. $\mathrm{He}$ found that policies might not be poverty-reducing in the short run, but in the long run. However, he claims that political economy constraints could prevent these policies from staying in place long enough to reach that poverty-reduction level.

Christiansen, et al. (2003) found that poverty headcount decreased in countries that also experienced an improvement in their macroeconomic policy scores. They also found that poverty decreased in those countries that experienced an improvement in their political risk score. Those countries that did not experience a reduction in poverty despite improvements in governance indicators, other factors such as droughts played a role. 
White and Anderson (2001) examine sectoral patterns of growth. They argued that the higher the initial Gini coefficient, the less the poor benefit from growth and there are apparent trade-offs between growth and distribution. More civil liberties tend to have a less pro-poor impact while more political freedom tends to have a more pro-poor impact while ethnic fragmentation appears to increase the poor's participation in the growth process. Agricultural growth tends to be less pro-poor while the opposite is true for growth in the services sector.

Kraay (2004) found that 60 percent to 95 percent of poverty changes are due to growth in average income while changes in income distribution are relatively more important in the short run. He also analysed that rule of law and accountability are both positively correlated with growth and distributional changes while openness to international trade has a positive correlation with growth and correlated with povertyreducing shifts in incomes.

All these studies suggest that good governance is pro-poor in terms of increasing incomes and reducing the poverty headcounts. Yet, they are less clear about what the intervention mechanism is i.e., increased growth, improved equity, or a combination of both that leads to such outcomes.

\section{DEFINING AND MEASURING GOVERNANCE AND PRO-POOR GROWTH}

\section{(a) Governance}

The concept of governance as referred in the development literature and discourse was originally used by specialists in Medieval English society, which was characterised by cooperation between the different sources of power i.e., church, nobility, merchants, peasant, etc. The term has also been widely used in international development; there are numerous interpretations of what the term actually describes.

Governance means process of decision-making and the process by which decisions are implemented. The quality of governance is determined by the impact of this exercise of power on the quality of life enjoyed by the citizens. Governance can be used in several contexts such as international governance, corporate governance, national governance and local governance. Government is one of the actors in governance.

Asian Development Bank (1995) identified four basic elements of good governance such as accountability, participation, predictability and transparency.

McCawley (2005) categorises governance issues at the macro and micro level. The macro level includes constitution, the overall rule of size and resources of the government, and relationship between legislators, the judiciary and the military, while micro issues of governance or government departments includes commercial firms, social institutions and civil society affairs.

United Nation Development Programme (1997) defines governance as the exercise of economic, political and administrative authority to manage a country's affairs at all levels. It comprises mechanisms, processes and institutions through which citizens and groups articulate their interests, exercise their legal rights, meet their obligations and mediate their differences. 
International Country Risk Guide (ICRG) covering 140 countries from 1980 to the present analyses and forecast risk for international investors. It includes 22 components that are grouped into three categories of risk: political, financial and economic. The political risk assessments are made on the basis of subjective analysis of the available information, while the financial and economic risk assessments are made solely on the basis of objective data. In determining the component rating, political risk contributes 50 percent to the rating while the other two categories contribute 25 percent each. The composite scores, ranging from zero to 100 , are then broken into categories from Very Low Risk (80 to 100 points) to Very High Risk (zero to 49.5 points).

World Bank aggregate governance indicators dataset developed by Kaufmann, et al. (2005) hereafter called the KK Datasets, is a set of world wide measures of six composite dimensions of governance perception indicators for 209 countries. These indicators are oriented so that higher value correspond to better outcomes, on a scale refers to the point estimates range from -2.5 to 2.5. These estimates are also rescaled and ranked in percentile (0-100). The lower percentile is ranked as worse off governance indicators whereas upper percentile is ranked as best governance for any given country. These perceptions may often be more meaningful than objective data, especially when it measures public faith in institutions. These averages of governance indicators are considered to capture institutional quality. These dimensions can be classified into three clusters with two indicators in each group is given as;

\section{Political Governance}

(i) Voice and accountability. (ii) Political instability and violence.

The political governance indicator is intended to capture the process by which government is selected, monitored and replaced. First indicator 'voice and accountability' measures political, civil and human rights and independence of the media. It includes a number of indicators measuring various aspects of political process, civil liberties and political rights. It measures the extent to which citizens of a country are able to participate in the selection of government while the 'political instability' indicator captures whether the government in power will be destabilised or overthrown by possibly unconstitutional or violent means, including military cop, terrorism etc.

\section{Economic Governance}

(i) Government effectiveness. (ii) Regulatory quality.

These two indicators summarise various indicators that include the government's capacity to effectively formulate and implement sound policies. The thrust of this index is on the input required government to be able to produce or implement good policies and quality delivery of public good. The 'regulatory quality' governance indicator includes measures of the incidence of market unfriendly policies such as price control or inadequate bank supervision, as well as the perceptions of the burdens imposed by excessive regulation in area such as foreign trade and business development.

\section{Institutional Dimension of Governance}
(i) Rule of law.
(ii) Control of corruption. 
The final dimensions of governance indicators are summarised in broad terms as the respect of citizen and the state of institutions that govern their interactions. Rule of law, summarises several indicators that measure the extent to which agents have confidence in and abide by the rules of the society. It measures the quality of contract enforcement, the police and the courts as well as likelihood of crime and violence. These indicators also measure a society's success in developing environment in which fair and predictable rules form basis for economic and social interactions. Control of corruption measures its perceptions conventionally defined as the exercise of public power for private gains. This aspect of corruption differs somewhat, ranging from the occurrence of additional payment to get things done, to assess the effect of corruption on business environment, to measure grand corruption in political arena or in the tendency of elites to engage in state capture. The presence of corruption is often a manifestation of a lack of respect on the part of both the corruptor and the corrupted for the rules that govern their interaction, thus represents a failure of governance.

The above two datasets are most commonly-used datasets in the cross country research on governance. Analysis on governance dimensions encompasses positive analysis from theory as well as prepositions concerning what government ought to be doing on the achievement of development outcomes.

\section{(b) Pro-poor Growth}

A positive growth is important but it is not sufficient to assess whether the poor indeed benefit or not. Thus, in assessing the impact of growth on poor, information on the distribution of gains from growth is necessary. That is, to determine whether growth is pro-poor, it is necessary to evaluate how the benefits of growth are shared amongst the different income groups.

Pro-poor growth is variously defined as follows:

- In its simplest interpretation, the concept of "pro-poor growth" implies the type of growth that is good for the poor; a reduction in the proportion of the poor in the population.

- Pro-poor growth is also defined as growth that results in an increase in the income of the poor.

- Pro-poor growth is defined as one that associates with larger proportionate increases in income of the poor than the rest of the population.

- Pro-poor growth that benefits the poor and provides them with opportunities to improve their economic situation.

For definition of pro-poor growth, the contribution of poverty measure, growth and inequality is important. In this context, poverty measure is based on distribution of real household incomes per capita or real household expenditure per capita, depending on which of the welfare indicator is used. Growth means an increase in the value of this welfare indicator. Inequality is taken as deviation of income from perfect equality measured by Gini coefficient. Pro-poor growth is concerned with the interrelation between the three elements, growth, poverty and inequality. The pro-poor growth literature assumes that the objective of the policy is to maximise the rate at which absolute poverty is reduced. 
There are many other definitions of pro-poor growth referred by some authors; Klasen (2001) approach for capturing pro-poor growth is measuring whether the per capita income growth rate of poor surpasses the average income growth rate. White and Anderson (2001) suggest that growth is pro-poor if poor's income grows more than the income of the non poor. Ravallion (2004) defines as any growth that reduces poverty is said to be pro-poor howsoever poor may receive only small fraction of total benefits of growth. Kakawani and Pernia (2000), and Son (2004) all suggest a measure of pro-poor growth that takes into account both reductions in poverty as well as improvement in inequality. Ravallion and Chen (2003) assume that growth is always pro-poor unless the incomes of the poor decline or stagnate. Miculloch and Baulch (1999) used poverty bias of growth measure by subtracting the real change in the poverty headcount between two time periods from the predicted change if there was an equal distribution of income. If poverty bias of growth is positive, then pro-poor growth occurred. Organisation such as Organisation of Economic Corporation and Development [OECD (2001) and the UN (2000)] have employed a very broad definition by classifying it as growth that benefits poor. [ADB (1999:6)] Growth is pro-poor when it is labour absorbing, and accompanied by policies and programs that mitigate inequalities and facilitate income and employment generation for the poor, particularly women and other traditionally excluded groups. There are many other definitions of pro-poor growth but the key elements of these definitions are that ensuing growth not only benefits the poor but they benefit disproportionately.

Finally, it is growth of the economic output that benefits the poor. If the reduction in absolute poverty is accepted as the measure of benefit for the poor, the greater the reduction in poverty incidence that growth generates, the more pro-poor it is. Since economic growth generally benefits the poor to some degree, the empirical question is not whether poor growth is or is not pro-poor, but what influences the extent to which it is pro-poor. The need is to find the kinds of economic growth for which the rate of poverty reduction is greatest, as well as to find the economic policy strategies that can produce growth of this kind.

\section{Governance in Pakistan}

Our analysis is based on aggregate governance indicators developed by Kaufmann, et al. (2005) hereafter called the KK Datasets, which is a set of world wide measures of six composite dimensions of governance covering the period from 1996 to 2005. These indicators measure subjective perceptions regarding the quality of governance with scores lie between -2.5 and 2.5 with higher scores corresponding to better outcomes. Within each indicator, countries are ranked by their total score and then allocated a number between 0 and 100.100 is associated with a high rating and one is associated with lower rating.

The political governance dimension in Pakistan refers to a country's voice and accountability and political stability. If political governance deteriorates or reclaims at low level, it may be reflected in whole disruptions, and a poor environment for protecting the rights and freedom of the masses, thus resulted in chaos. Table 1 reports the indices of political governance from 1996 to 2005. The performance of Pakistan political governance deteriorated after the military took over the Nawaz regime. Although the 
Table 1

Country Snapshot of Political Governance Indicators

\begin{tabular}{lccccc}
\hline & \multicolumn{2}{c}{ Voice and Accountability } & & \multicolumn{2}{c}{ Political Stability } \\
\cline { 2 - 3 } \cline { 5 - 6 } Years & Estimates & $\begin{array}{c}\text { Percentile } \\
\text { Rank }\end{array}$ & & Estimates & $\begin{array}{c}\text { Percentile } \\
\text { Rank }\end{array}$ \\
\hline 1996 & -1.06 & 20.2 & -1.41 & 9.0 \\
1998 & -0.68 & 30.4 & & -1.21 & 11.8 \\
2000 & -1.57 & 6.8 & & -0.88 & 19.3 \\
2002 & -1.12 & 17.4 & & -1.51 & 11.3 \\
2003 & -1.18 & 14.0 & & -1.58 & 8.0 \\
2004 & -1.31 & 11.6 & -1.67 & 5.7 \\
2005 & -1.23 & 12.6 & -1.68 & 5.7 \\
\hline
\end{tabular}

Source: Kaufmann, et al. $(1996,2005)$ Estimates range from (-2.5 to +2.5) Percentile ranked (0-100).

military government has adopted reforms agenda which is not as strong and far reaching as was expected given the deep rooted structural problems of the economy. The two indicators, voice and accountability and political stability ranked in lower percentile and portray a dismal picture. The so called democratically elected government in power is centralised in the hand of military dictator. Local government is weak with little administrative and financial authority. Organisation, such as Accountability Bureau serves more as the agents of the government in power than autonomous, non-partisan. The military had a tremendous influence on politics, civilian decision-making and patronage. The civilian leaders took cognizance of the military to get support on their side. Senior positions in the government, public enterprise and public banks, and allocations of urban land at the heavily subsidised rates are offered to them [HDC (1999)].

The poor political governance has affected domestic resource mobilisation. Pakistan has one of the lowest tax-GDP ratio that summarises various indicators of government's ability to formulate and implement sound policies.

Table 2

Country Snapshot of Economic Governance Indicators

\begin{tabular}{|c|c|c|c|c|}
\hline \multirow[b]{2}{*}{ Years } & \multicolumn{2}{|c|}{ Government Effectiveness } & \multicolumn{2}{|c|}{ Regulatory Quality } \\
\hline & Estimates & $\begin{array}{c}\text { Percentile } \\
\text { Rank }\end{array}$ & Estimates & $\begin{array}{c}\text { Percentile } \\
\text { Rank }\end{array}$ \\
\hline 1996 & -0.39 & 40.0 & -0.54 & 25.5 \\
\hline 1998 & -0.74 & 22.0 & -0.20 & 37.4 \\
\hline 2000 & -0.53 & 33.5 & -0.81 & 18.7 \\
\hline 2002 & -0.57 & 33.0 & -0.83 & 21.2 \\
\hline 2003 & -0.56 & 34.9 & -0.78 & 20.7 \\
\hline 2004 & -0.52 & 37.3 & -0.89 & 18.7 \\
\hline 2005 & -0.53 & 34.0 & -0.68 & 27.7 \\
\hline
\end{tabular}


Economic governance refers to a country's government effectiveness and regulatory quality. The performance of economic governance is better as compared to political governance in Pakistan. The government effectiveness indicator ranked at thirtieth percentile and has better estimates in all the years in consideration while ranking of regulatory quality indicator fluctuate in the same period. The quality of economic governance is critical to poverty reduction, Good economic governance facilities participatory, pro-poor policies as well as sound macroeconomic management. The economic governance in case of Pakistan has performed relatively poor during 90s.

The institutional dimensions governance indicators which include rule of law and control of corruptions established the primacy of institutions for well-functioning market economy for Pakistan. Table 3 summarises the low score gained in the governance indicators hence ranked at the lowest percentile in the world. Corruption hampers achievement of the Millennium Development Goals by undermining the economic growth and sustainable development that would free millions from the poverty trap. Fighting corruption must be central plan to increase resources to achieve the goals. A Transparency International survey of 163 countries based on perceived levels of corruption also saw Pakistan slip down two places compared to its ranking of 145 last year, suggesting a rise in corruption in 2006.

Table 3

Country Snapshot of Institutional Dimensions of Governance Indicators

\begin{tabular}{lccccc}
\hline & \multicolumn{2}{c}{ Rule of Law } & & \multicolumn{2}{c}{ Control of Corruption } \\
\cline { 2 - 3 } \cline { 5 - 5 } Years & Estimates & Percentile Rank & & Estimates & Percentile Rank \\
\hline 1996 & -0.49 & 35.9 & -1.04 & 12.2 \\
1998 & -0.79 & 25.0 & & -0.82 & 18.6 \\
2000 & -0.75 & 26.4 & & -0.94 & 16.2 \\
2002 & -0.75 & 27.4 & -0.85 & 23.5 \\
2003 & -0.69 & 28.8 & -0.76 & 27.5 \\
2004 & -0.83 & 21.6 & -1.06 & 11.3 \\
2005 & -0.81 & 24.2 & -1.01 & 15.8 \\
\hline
\end{tabular}

Source: Kaufmann, et al. $(1996,2005)$ Estimates range from (-2.5 to +2.5) Percentile rank (0-100).

\section{Pro-poor Growth in Pakistan}

There are three dimensions of pro-poor growth: poverty, inequality and growth. The concept of "pro-poor growth" very much reflects the notion of "redistribution with growth". A better quality of life for the poor calls for higher incomes. As income per capita rise, several aspects of quality of life improves in varying degrees but not all, not at the same rate and not inevitably.

Pro-poor growth occurs when economic growth disproportionately benefits the poor. One approach for capturing pro-poor growth is measuring whether the per capita income/expenditure growth rate of the poor surpasses the average income /expenditure growth rate [Klasen (2002)]. Table 4 gives the statistic of mean and growth rate of consumption expenditure by quintile in two periods, 2000-01 to 2004-05. The analyses 
Table 4

Consumption Expenditure by Quintile at the Prices of 2001(Rs)

\begin{tabular}{lccc}
\hline Quintile & PIHS 2000-01 & PSLM 2004-05 & Growth (\%) \\
\hline Poorest 20\% & 508 & 555 & 9.25 \\
Second 20\% & 690 & 775 & 12.32 \\
Third 20\% & 845 & 961 & 13.73 \\
Fourth 20\% & 1070 & 1238 & 15.70 \\
Richest 20\% & 1908 & 2327 & 21.96 \\
Average & 1001 & 1171 & 16.63 \\
\hline
\end{tabular}

Source: Pakistan, 2004-05.

shows that although the mean per capita consumption expenditure increased in all quintiles but the real mean expenditure growth in richest 20 percent population at 22 percent is nearly 2.5 times that of poorest 20 percent, hence show that growth is not propoor.

Another concept is that the growth is always pro-poor unless the incomes of the poor decline or stagnate [Ravallion and Chen (2003)]. According to this approach, growth becomes pro-poor because per adult expenditure has increased overtime.

Table 5 compares the growth rate in per adult equivalent consumption expenditure on commodity groups across two points in time. The rate of growth in expenditure is greater for top 20 percent as compared to bottom 20 percent population. White and Anderson (2001) suggest that growth is pro-poor if poor's income grows more than the incomes of the non poor.

Table 5

Growth in Monthly Real Consumption Expenditure by Commodity Groups

\begin{tabular}{|c|c|c|}
\hline Commodity Groups & $\begin{array}{c}\text { Poorest } 20 \% \\
\text { (2000-01 to } 2004-05)\end{array}$ & $\begin{array}{c}\text { Richest } 20 \% \\
(2000-01 \text { to } 2004-05)\end{array}$ \\
\hline Food & 11.6 & 19.0 \\
\hline Fuel and Lighting & 5.7 & 20.0 \\
\hline Clothing & -2.2 & 8.4 \\
\hline Housing & 9.3 & 16.8 \\
\hline Health & 14.6 & -6.1 \\
\hline Education & -13.7 & 11.9 \\
\hline Miscellaneous & 15.4 & 54.4 \\
\hline
\end{tabular}

Source: Pakistan, 2004-05.

Table 6 demonstrates the share in income and consumption expenditure and Gini coefficient over time. It is observed that both income and expenditure share for poorest 20 percent has decline while the share of richest 20 percent has increased. The ratio of highest to lowest income group has also increased between the two periods. In the same way Gini coefficient for income and expenditure also increased over time. 
Table 6

Share of Income and Consumption Expenditure by Quintile

\begin{tabular}{|c|c|c|c|c|}
\hline \multirow[b]{2}{*}{ Quintile } & \multicolumn{2}{|c|}{$2000-01$} & \multicolumn{2}{|c|}{$2004-05$} \\
\hline & Income & Expenditure & Income & $\overline{\text { Expenditure }}$ \\
\hline Poorest $20 \%$ & 6.4 & 10.1 & 6.2 & 9.5 \\
\hline Richest $20 \%$ & 49.6 & 38.0 & 50.4 & 39.4 \\
\hline Ratio of $\mathrm{H} / \mathrm{L}$ & 7.9 & 3.7 & 8.1 & 4.2 \\
\hline Gini Coefficient & 0.41 & 0.27 & 0.42 & 0.29 \\
\hline
\end{tabular}

Source: (i) Pakistan, 2004-05. (ii) Anwer (2005).

Dimensions of pro-poor growth in Table 7 indicate that poverty and inequality have increased over time but in 2004-05 percentage of poor population has decreased. Income share of bottom 20 percent decreased after 1998-99. The picture emerged from this table that according to Kakawani and Pernia (2000) definition growth is not pro-poor during this period.

Table 7

\begin{tabular}{lccc}
\multicolumn{4}{c}{ Dimensions of Pro-poor Growth } \\
\hline $\begin{array}{c}\text { Poverty } \\
\text { Years }\end{array}$ & of Poor & $\begin{array}{c}\text { Growth } \\
\text { Households })\end{array}$ & $\begin{array}{c}\text { (Gini Coefficient) } \\
\text { (Income Share of } \\
\text { Bottom 20\%) }\end{array}$ \\
\hline $2000-01$ & 27.61 & 0.41 & 6.42 \\
$2001-02$ & 29.17 & 0.41 & 6.36 \\
$2002-03$ & 30.90 & 0.42 & 6.30 \\
$2003-04$ & 32.78 & 0.42 & 6.24 \\
$2004-05$ & $29.3^{*}$ & 0.42 & 6.20 \\
\hline Source: (i) Social Policy and Development Centre, 2005-06. (ii) Anwar $(2006)$ &
\end{tabular}

Source: (i) Social Policy and Development Centre, 2005-06. (ii) Anwar (2006).

Table 8 shows inflation over time by food/non-food and by the lowest and the highest income groups. In recent year food and non food inflation has increased. Food inflation has increased more sharply than non food inflation and lowest income group suffer more as compared to upper income group. Household Income and Expenditure Survey data indicates that expenditure share of poorest 20 percent population is approximately 58 percent as compared to 40 percent of richest 20 percent population which demonstrates that inflation effects disproportionately more to poor than non poor population. 
Table 8

Inflation in Pakistan

\begin{tabular}{|c|c|c|c|c|c|}
\hline Years & Inflation & $\begin{array}{c}\text { Food } \\
\text { Inflation }\end{array}$ & $\begin{array}{l}\text { Non-food } \\
\text { Inflation }\end{array}$ & $\begin{array}{l}\text { Inflation for } \\
\text { Lowest } \\
\text { Income } \\
\text { Group }\end{array}$ & $\begin{array}{c}\text { Inflation for } \\
\text { Highest } \\
\text { Income } \\
\text { Group }\end{array}$ \\
\hline $2000-01$ & 4.4 & 3.6 & 5.1 & 4.5 & 4.7 \\
\hline 2001-02 & 3.5 & 2.5 & 4.3 & 3.0 & 3.6 \\
\hline $2002-03$ & 3.1 & 2.9 & 3.2 & 2.9 & 3.1 \\
\hline 2003-04 & 4.6 & 6.0 & 3.7 & 5.3 & 4.3 \\
\hline 2004-05 & 9.3 & 12.5 & 7.1 & 10.2 & 8.9 \\
\hline
\end{tabular}

Source: Pakistan, 2004-05.

In Pakistan it has been realised that growth alone is not sufficient for poverty reduction in development policy and practice. During the last few years pro-poor expenditures were the most important fiscal intervention to support the critical elements of the poverty reduction strategy. The percentage share of social sector and poverty related expenditure in Pakistan is reflected in Table 9. It is analysed that the percentage share of expenditure of safety nets which is to cater to the needs of the poor and vulnerable sections of the society has decreased overtime.

It is concluded that in Pakistan, government knowingly or unknowingly adopt policies that are biased in favour of the rich. Consequently, the gap in well being between the 'haves' and 'haves not' tends to persist, if not widen, over time. So to foster the overall well being of the society, government needs to pursue policies that will reduce this gap.

Table 9

Governance, Social Sector and Poverty Related Expenditure

\begin{tabular}{lccc}
\hline Sectors & \% Share 2001-02 & \% Share 2004-05 & Growth (\%) \\
\hline Community Services & 6.6 & 13.8 & 109.1 \\
Human Development & 54.2 & 49.2 & -9.2 \\
Rural Development & 14.5 & 18.8 & 29.6 \\
Safety Nets & 4.9 & 2.7 & -44.8 \\
Governance & 20.0 & 15.9 & -20.5 \\
Total (Rs Billion) & 167.25 & 316.24 & 89.2 \\
\hline
\end{tabular}

Source: Computation based on Pakistan, 2004-05.

\section{ANALYSIS}

This section examines the linkages between the governance and pro-poor growth in Pakistan by using perception based data to measure governance. The analysis focus on at least two of the three dimensions of pro-poor growth: poverty, inequality and growth. Table 1 presents results estimated by Ordinary Least Square (OLS) to estimate econometrically whether voice of accountability, Political Stability, Regularity quality, Rule of Law, and Control of Corruption have an impact on poverty. 
Table 10

Linkages between Governance and Poverty

\begin{tabular}{lccc}
\hline $\begin{array}{l}\text { Indicators of } \\
\text { Governance }\end{array}$ & $\begin{array}{c}\text { Standardised } \\
\text { Coefficient }(\beta)\end{array}$ & T-Statistic & R Square \\
\hline Voice and & -0.488 & $-1.581^{* * * *}$ & 0.488 \\
Accountability & & & \\
Political Stability & -0.628 & $-2.28^{* *}$ & 0.628 \\
Govt. Effectiveness & 0.080 & 0.228 & 0.080 \\
Regulatory Quality & -0.649 & $-2.41^{* * *}$ & 0.42 \\
Rule of Law & -0.613 & $-2.19^{* *}$ & 0.376 \\
Control of Corruption & -0.035 & -0.099 & 0.001 \\
\hline
\end{tabular}

Note: The $t$-values significant at 5 percent and 10 percent levels are indicated by $* *, * * *$.

The results show that political indicators which include voice and accountability and political stability are negatively and significantly correlated with poverty which concludes that while greater accountability and political stability may be associated with reduction in poverty. The economic indicator of governance shows that regulatory quality has a negative and statistically significant impact on reducing the percentage of the population below the poverty line. The institutional dimensions of governance uncover a negative and significant association between rule of law and poverty.

Table 11

Linkages between Governance and Income Inequality

\begin{tabular}{lccc}
\hline & Standardised & & \\
Indicators of Governance & Coefficient $(\beta)$ & T- Statistic & R Square \\
\hline Voice and Accountability & -0.550 & $-1.86^{* * * *}$ & 0.30 \\
Political Stability & -0.546 & $-1.84^{* * * *}$ & 0.29 \\
Govt. Effectiveness & 0.114 & 0.324 & 0.013 \\
Regulatory Quality & -0.748 & $-3.18^{* *}$ & 0.559 \\
Rule of Law & -0.549 & $-1.86^{* * *}$ & 0.30 \\
Control of Corruption & 0.036 & -0.103 & 0.001 \\
\hline
\end{tabular}

Note: The $t$-values significant at 1 percent, 5 percent and 10 percent levels are indicated by $*, * *, * * *$.

Inequality refers to the deviation of income from perfect equality as measured by Gini Coefficient. It is not a final outcome of growth but plays a central role in determining the rate and pattern of growth. Table 11 suggests relationship between governance indicators and inequality by applying simple OLS regressions. The analysis synthesised that voice of accountability and political stability regularity quality and rule of law indicators, all exhibit a negative and significant relationship with inequality. In other words, better governance indicators lead to a decrease in inequality.

\section{CONCLUSIONS}

The aim of this study is to explore linkages between governance and pro-poor growth in Pakistan for the period 1996 to 2005. The analysis shows that governance 
indicators which include voice and accountability, political instability and violence, government effectiveness, regulatory burden, rule of law and control of corruption have low scores and ranked at the lowest percentile as compared to other countries. The dimensions of pro-poor growth which include poverty, inequality and growth indicate that poor does not benefit proportionately from the economic growth. It is also analysed that incidence of poverty has increased, income inequality has worsened and poor's share in income and expenditure have also decreased. The econometric analysis of linkages between governance and pro-poor growth suggest a negative and significant relationship which leads to reduction in poverty and inequality. It is concluded that greater voice and accountability, political instability, regulatory burden, rule of law can control the corruption and pro-poor policies which ultimately reduce poverty and inequality in the long run.

Finally, the results on the performance of Pakistan for governance dimensions portray an unfavourable situation. Weak governance is not conducive environment for entrepreneurs for long term investment. To face challenge of good governance, Pakistan needs to formulate and effectively implement its governance policies to improve governance dimensions, taking account of higher growth and halving poverty by 2015 .

\section{REFERENCES}

Asian Development Bank(1995) Governance: Sound Development Management. Manila: Asian Development Bank.

Ahmed, S. (2001) Poverty Reduction and Governance in South Asia. Mahbub ul Haq Human Development Review 1:1.

Anwer, Talat (2005) Long Term Changes in Income Distribution in Pakistan: Evidence Based on Consistent Series of Estimates. Centre for Research on Poverty Reduction and Income Distribution. (Discussion Paper Series No.03.)

Anwer, Talat (2006) Measurement of Absolute Poverty and Governance in Pakistan: 1998-99 and 2004-05. Paper presented at 22nd Annual General Meeting and Conferences of Pakistan Society of Development Economists.

Chatterjee, Bipul. (2006) Institutions and Pro-poor Growth in Bangladesh. Institute of Pro-poor Growth, UK. (Working Paper Series No.2.)

Chong, A and M. Gradstien (2004) Inequality and Institutions. Inter-American Development Bank, New York. (Research Department Working Paper No. 506).

Christiansen, L., L. Demery, and S. Paternostro (2003) Macro and Micro Perspectives of Growth and Poverty in Africa. The Work Bank Economic Review 17, 317-347.

Dollar, D. and A. Kraay (2002) Growth is Good for the Poor. Journal of Economic Growth 7, 195-225.

Hassan, Mian Tayyab (2002) Governance and Poverty in Pakistan. Pakistan Institute of Development Economics. (MIMAP Technical Paper No.13.) http:// info.worldbank.org/governance/kkz2005/country_report.asp. http://www.prsgroup.com/ICRG_Methodology.aspx\#Background

Kakwani, N. and E. Pernia (2000) What is Pro-poor Growth? Asian Development Review $18: 1$.

Kaufmann, D. and A. Kraay (2002) Growth without Governance. Washington, DC, World Bank. (World Bank Policy Research Working Paper No. 2928.) 
Kaufmann, D., A. Kraay, and M. Mastruzzi (2005) Governance Matters IV: Governance Indicators for 1996-2004. World Bank, Washington, DC.

Kimnenyi, Mwangi S. (2005) Institutions of Governance, Power Diffusion and Pro-poor Growth Policies. Paper presented at the VII Senior Policy Seminar organised by AERC, Cape Town Johannesburg, South Africa, March.

Klasen, S. (2002) In Search of the Holy Grail: How to Achieve Pro-poor Growth? Paper Commissioned by GTZ, University of Munich.

Kraay, A. (2004) When is Growth Pro-Poor? Cross-country Evidence. Washington, DC, World Bank. (World Bank Policy Research Working Paper 3225).

Lopez, J. H. (2004b) Pro-growth, Pro-poor: Is there a Tradeoff? World Bank, Washington, DC. (World Bank Policy Research Working Paper 3378).

Mahbub ul Haq Human Development Centre (1999) Human Development in South Asia, The Crisis of Governance. Mahbub ul Haq Human Development Centre and the Oxford University Press, Pakistan.

McCawley Peter (2005) Governance in Indonesia: Some Comments. Tokyo. (ADBI Research Policy Brief No.17).

McCulloch, Neil, and B. Baulch (1999) Assessing the Poverty Bias of Economic Growth: Methodology and Application to Andhra Pradesh. Institute of Development Studies, Brighton. (Working Paper No. 98.)

Moore,M., J. Leavy, P. Houtzager, and H. White (1999) Polity Qualities: How Governance Affects Poverty. Institute for Development Studies, University of Sussex: Brighton,UK. (IDS Working Paper No.99)

OECD (2001) Rising to the Global Challenge: Partnership for Reducing World Poverty. Statement by the DAC High level Meeting, April 25-26, OECD. Paris, France.

Pakistan, Government of (2005-2006) Pakistan Economic Survey. Islamabad: Ministry of Finance.

Pasha, Hafiz A. (2000) Elements of Good Economic Governance. Social Policy Development Centre. (Research Report No. 30).

Ravallion, M. and S. Chen (2003) Measuring Pro-poor Growth. Economic Letters 78, 93-99.

Resnick and Regina Birner (2006) Does Good Governance Contribute to Pro-poor Growth?: A Review of the Evidence from Cross-Country Studies. International Food Policy Research Institute.

Social Policy and Development Centre (2005-06) Social Development in Pakistan. Annual Review. Karachi.

Son, Hyun Hwna (2004) A Note on Measuring Pro-poor Growth. Economic Letters 82, 307-314.

UNDP (1997) Governance for Sustainable Human Development. New York: Management and Governance Division, Bureau for Policy and Programme Support.

United Nations (2000) A Better World for All. New York: United Nations.

White, H. and E. Anderson (2001) Growth versus Distribution: Does the Pattern of Growth Matter? Development Policy Review 19:3, 267-289.

World Bank (2005a, 2005b) Governance Indicators: 1996-2004. Washington, DC: World Bank. 


\section{Comments}

The paper has addressed an important question: Does good governance contribute to pro-poor growth? It has used the governance indicators developed by Kaufmann, et al. (2005) covering the period from 1996 to 2005. Governance indicators have three dimensions: political (voice and accountability and political stability), economic (government effectiveness and regulatory quality) and institutional (rule of law and control of corruption). For the pro-poor growth the paper has used the concept whether the per capita income/expenditure growth rate of the poor surpasses the average income/expenditure growth rate although it has also discussed some other concepts for the pro-poor growth. Most of these concepts reveal that growth is not pro-poor in Pakistan between 2000-01 and 2004-05 period. Food inflation has increased more sharply than non-food inflation and lowest income group has suffered more as compared to upper income group. Despite an increase in expenditure in the pro-poor sectors, including safety nets, the paper concluded that the gap in well being between the 'have' and 'have not' tends to persist, if not widen, over time. To establish the relationship between governance and pro-poor growth, the paper estimated the OLS whether voice of accountability, political stability, regularity quality, rule of law and control of corruption have an impact on poverty and inequality, and found a significant relationship between good governance and reduction in both poverty and inequality.

The paper has contributed to knowledge in terms of understanding the relationship between growth and governance indicators. However, it has several flaws. It is based on a small number of observations; it is thus difficult to generalise its findings. It ignores the role of other macro and micro level factors on both poverty and inequality. Readers would have been benefited more if the authors have discussed the mechanism through which the governance indicators have influenced poverty and inequality, particularly in Pakistan.

Pakistan Institute of Development Economics,

G. M. Arif

Islamabad. 